\title{
Insertion of Zinc into the Cyclophosphazene Skeleton: Synthesis and Structure of Six-Membered- Ring Complexes of Zine
}

\author{
Sushil K. Pandey, Alexander Steiner, Herbert W. Roesky," and Dietmar Stalke \\ Institute of Inorganic Chemistry, University of Goettingen, D-37077 Goettingen, Germany
}

Received June 25, $1993^{\circ}$

Cyclozincaphosphazenes have been synthesized by the reaction of the bis-silylated ligand $\mathrm{HN}\left[\mathrm{P}(\mathrm{NMe})_{2} \mathrm{NSiMe}_{3}\right]_{2}$ (1) with $\mathrm{ZnR}_{2}(2)\left(\mathrm{R}=\mathrm{N}\left(\mathrm{SiMe}_{3}\right)_{2}, \mathrm{Me}, \mathrm{Et}\right)$. These complexes have been characterized by IR, NMR, and mass spectroscopy and by $X$-ray crystal structural analysis. X-ray analysis of $\left[\mathrm{N}\left\{\mathrm{P}\left(\mathrm{NMe}_{2}\right)_{2} \mathrm{NSiMe}_{3}\right\}_{2} \mathrm{ZnN}\left(\mathrm{SiMe}_{3}\right)_{2}\right](3)$ revealed that it crystallizes as a monomer in the solid state.

\section{Introduction}

In the last two decades transition metal complexes of acyclic phosphazenes have been investigated. ${ }^{1-5}$ However, in recent years the syntheses of cyclometallaphosphazenes having transition metals as building blocks in ring skeletons have created an interesting new field of organometallic chemistry, ${ }^{6-8}$ The studies on cyclic zinc amides have been quite limited. ${ }^{9}$ In contrast, the syntheses of $\mathrm{Zn}-\mathrm{O}$ and $\mathrm{Zn}-\mathrm{S}$ heterocycles are known. ${ }^{10}$ Recently, the synthesis and structure of a dimeric species, cyclozincdisilatriazene, were reported by our laboratory. ${ }^{11}$ So, in view of these findings, it was considered worthwhile to synthesize the cyclophosphazene derivatives of zinc. Herein we report the synthesis of cyclophosphazenes containing zinc in the phosphazene ring and the $\mathrm{X}$-ray structure of $\left[\mathrm{N}\left(\mathrm{P}\left(\mathrm{NMe}_{2}\right)_{2} \mathrm{NSiMe}\right\}_{2} \mathrm{ZnN}\right.$ $\left.\left(\mathrm{SiMe}_{3}\right)_{2}\right](3)$.

\section{Results and Discussion}

The acyclic bis-silylated phosphazene moiety $\mathrm{HN}\left[\mathrm{P}\left(\mathrm{NMe}_{2}\right)_{2-}\right.$ $\left.\mathrm{NSiMe}_{3}\right]_{2}(1)$ reacts with $\mathrm{Zn}\left[\mathrm{N}\left(\mathrm{SiMe}_{3}\right)_{2}\right]_{2}, \mathrm{ZnMe}_{2}$, and $\mathrm{ZnEt}{ }_{2}$ in 1:1 molar ratios resulting in the formation of cyclic derivatives 3-5, respectively. The pathways for the reaction can be depicted as follows:

$$
\begin{aligned}
& \mathrm{HN}\left[\mathrm{P}\left(\mathrm{NMe}_{2}\right)_{2} \mathrm{NSiMe}_{3}\right]_{2}+
\end{aligned}
$$

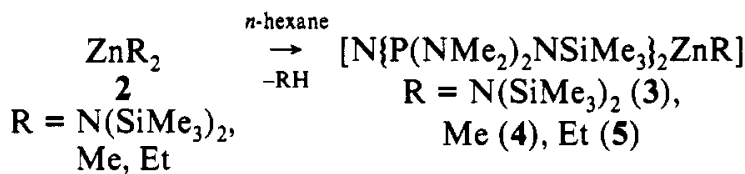

It is found that monocyclic complexes are the final products,

- Abstract published in Advance ACS Abstracts, October 15, 1993

(1) Allcock, H. R. Phosphorus-Nitrogen Compounds; Academic Press: New York, 1972

(2) Greigger, P. P.; Allcock; H. R. J. Am. Chem. Soc. 1979, 101, 2492.

(3) Allcock, H. R.; Greigger, P. P.; Wagner, L. J; Bernheim, M. Y. Inorg. Chem. 1981, 20,716.

(4) Allcock, H. R.; Wagner, L. J.; Levin, M. L. J. Am. Chem. Soc. 1983 105, 1321 .

(5) Allcock, H. R.; Riding, G. H.; Whittle, R. R. J. Am. Chem. Soc. 1984, 106, 5561 .

(6) Roesky, H. W.; Katti, K. V.; Seseke, U.; Witt, M.; Egert, E.; Herbst, R.; Sheldrick, G. M. Angew. Chem. 1986, 98, 447; Angew. Chem., Int. Ed. Engl. 1986, 25, 477.

(7) Roesky, H. W. Synlett 1990, 651

(8) Hasselbring, R.; Roesky, H. W.; Noltemeyer, M. Angew. Chem. 1992. 104, 613; Angew. Chem. Int. Ed. 1992, 31, 601.

(9) Lappert, M. F.; Power, P. P.; Sanger, A. R.; Srivastava, R. C. Metal and Metalloid Amides; Ellis Harwood Limited: Chichester, U.K., 1980 p 585.

(10) Power, P. P. J. Organomet. Chem. 1990, $400,49$.

(11) Anil, J. S.; Schmidt, H.-G.; Noltemeyer, M.; Roesky, H. W. Organometallics 1992, 11, 462
Table I. Crystallographic Data for 3

\begin{tabular}{ll}
\hline chem formula & $\mathrm{C}_{20} \mathrm{H}_{60} \mathrm{~N}_{\mathrm{B}} \mathrm{P}_{2} \mathrm{Si}_{4} \mathrm{Zn}$ \\
space group & $C 2 / c$ \\
$\mathrm{fw}$ & 652.43 \\
$T(\mathrm{~K})$ & $153(1)$ \\
$a(\mathrm{pm})$ & $2023.3(4)$ \\
$b(\mathrm{pm})$ & $1173.2(3)$ \\
$c(\mathrm{pm})$ & $1695.3(4)$ \\
$\beta(\mathrm{deg})$ & $117.56(1)$ \\
$V\left(\mathrm{~nm}^{3}\right)$ & $3.568(1)$ \\
$Z$ & 4 \\
crystal size & $0.5 \times 0.3 \times 0.3$ \\
$\left.\rho_{\text {calc }}(\mathrm{g} \mathrm{cm})^{-3}\right)$ & 1.215 \\
$\mu(\mathrm{Mo} \mathrm{K \alpha})\left(\mathrm{cm}^{-1}\right)$ & 0.936 \\
$F(000)$ & 1408 \\
$2 \theta$ range (deg) & $8-55$ \\
no. of reflns measd & 4295 \\
no. of unique reflns & 4119 \\
no. of reflns used & 4118 \\
$R_{\mathrm{w} 2}(\text { all data })^{\circ}$ & 0.109 \\
$R_{1}(F>4 \sigma(F))^{a}$ & 0.041 \\
$g_{1}$ & 0.0685 \\
$g_{2}$ & 2.556 \\
no. of refined params & 170 \\
$\left.\rho(\mathrm{e} \mathrm{nm})^{-3}\right)$ & 896 \\
${ }^{a} R_{1}=\sum \mid F_{\mathrm{o}}-F_{\mathrm{c}} / \sum F_{\mathrm{o}}$ and $R_{\mathrm{w} 2}=\left[\sum w\left(F_{0}{ }^{2}-F_{\mathrm{c}}{ }^{2}\right)^{2} / \Sigma w F_{0}{ }^{4}\right]^{1 / 2}$.
\end{tabular}

even when the reactions are carried out in a 2:1 molar ratios and forcing conditions such as higher boiling solvents and long refluxing times are used. The versatility of the bonding mode of the ligand is noteworthy here; in complexes 3-5, bidentate modes of attachment are observed, while in case of an alkaline earth metal, e.g. Ba, the mode of bonding is tridentate. ${ }^{12}$

The electron impact mass spectra indicate the monomeric species in the gas phase; for 3 the ion at $m / z 489(62 \%, M-N$ $\left.\left(\mathrm{SiMe}_{3}\right)_{2}\right)$ and for 5 the peak at $m / z 490(100 \%, \mathrm{M}-\mathrm{Me})$ are found. The characteristic absorptions for $\mathrm{P}-\mathrm{N}$ bonds were found between 1135 and $1289 \mathrm{~cm}^{-1}$ in the IR spectra of these compounds, indicating the formation of a phosphazene ring. ${ }^{1} \mathrm{H}$ NMR gives the characteristic resonance pattern, the signal for the methyl protons of $\mathrm{NMe}_{2}$ appearing as a doublet $(\delta 2.6 \mathrm{ppm}$ with $J=10.5$ $\mathrm{Hz}$ ), which is in accordance with the symmetry of the ring system. In the ${ }^{31} \mathrm{P}$ NMR spectra, one singlet is observed in each case with a downfield chemical shift, showing the equivalence of phosphorus nuclei in the molecule.

\section{X-ray Structure of 3}

Important bond lengths and angles are listed in Table III. Compound 3 crystallizes as a monomer in the solid state (Figure

(12) Pandey, S. K.; Steiner, A.; Roesky, H. W.; Stalke, D. Angew. Chem. 1993, I05, 625; Angew. Chem., Int. Ed. Engl. 1993, 32, 596. 


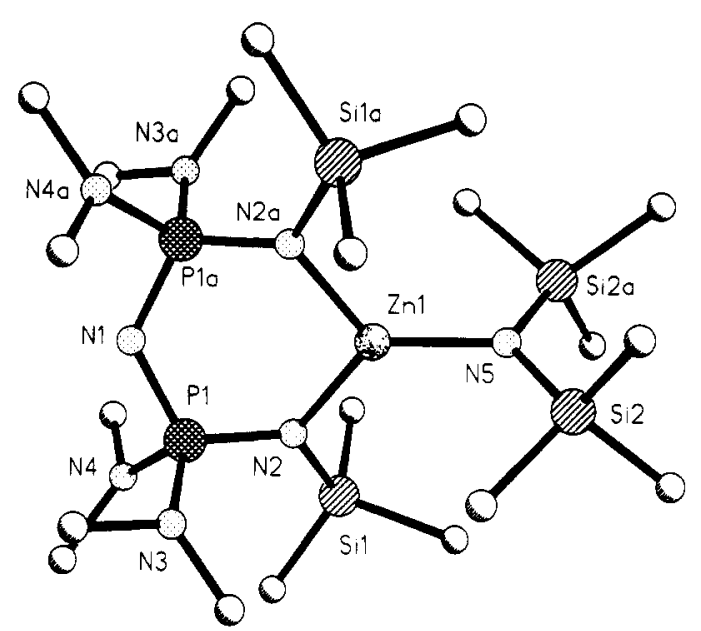

Figure 1. Molecular structure of $\left[\mathrm{N}\left\{\mathrm{P}\left(\mathrm{NMe}_{2}\right)_{2} \mathrm{NSiMe}_{3}\right\}_{2} \mathrm{ZnN}\left(\mathrm{SiMe}_{3}\right)_{2}\right]$ (3), giving the numbering scheme used in Tables II and III.

Table II. Atomic Coordinates $\left(\times 10^{4}\right)$ and Equivalent Isotropic Displacement Parameters $\left(\mathrm{pm}^{2} \times 10^{-1}\right)$ for $3^{a}$

\begin{tabular}{llrll}
\hline & \multicolumn{1}{c}{$x$} & $y$ & \multicolumn{1}{c}{$z$} & $U(\mathrm{eq})$ \\
\hline $\mathrm{Zn}(1)$ & 5000 & $1908.0(3)$ & 2500 & $16.8(2)$ \\
$\mathrm{P}(1)$ & $4226.3(3)$ & $-333.1(5)$ & $1820.7(3)$ & $17.3(2)$ \\
$\mathrm{Si}(1)$ & $3244.7(3)$ & $1529.1(6)$ & $1880.2(4)$ & $23.3(3)$ \\
$\mathrm{Si}(2)$ & $4957.2(4)$ & $4201.9(6)$ & $1578.7(5)$ & $32.2(4)$ \\
$\mathrm{N}(1)$ & 5000 & $-859(2)$ & 2500 & $22.1(12)$ \\
$\mathrm{N}(2)$ & $4083.6(9)$ & $961(2)$ & $2012.9(11)$ & $18.2(8)$ \\
$\mathrm{N}(3)$ & $4162.4(10)$ & $-397(2)$ & $813.0(12)$ & $24.1(9)$ \\
$\mathrm{N}(4)$ & $3566.8(10)$ & $-1178(2)$ & $1812.4(13)$ & $26.6(9)$ \\
$\mathrm{N}(5)$ & 5000 & $3545(2)$ & 2500 & $24.6(14)$ \\
$\mathrm{C}(1)$ & $4444(2)$ & $-1381(2)$ & $533(2)$ & $35.4(14)$ \\
$\mathrm{C}(2)$ & $3642(2)$ & $297(2)$ & $75(2)$ & $34.1(14)$ \\
$\mathrm{C}(3)$ & $3088(2)$ & $-1907(2)$ & $1084(2)$ & $39.8(13)$ \\
$\mathrm{C}(4)$ & $3593(2)$ & $-1480(3)$ & $2659(2)$ & $39.0(14)$ \\
$\mathrm{C}(5)$ & $2389.5(13)$ & $702(3)$ & $1158(2)$ & $41.2(11)$ \\
$\mathrm{C}(6)$ & $3278(2)$ & $1664(3)$ & $2995(2)$ & $42.5(15)$ \\
$\mathrm{C}(7)$ & $3092.7(14)$ & $2960(2)$ & $1350(2)$ & $32.2(12)$ \\
$\mathrm{C}(8)$ & $4287(2)$ & $5420(3)$ & $1177(2)$ & $53(2)$ \\
$\mathrm{C}(9)$ & $5865(2)$ & $4826(3)$ & $1744(2)$ & $56(2)$ \\
$\mathrm{C}(10)$ & $4661(2)$ & $3136(3)$ & $653(2)$ & $40(2)$
\end{tabular}

a $U(\mathrm{eq})$ is defined as one-third of the trace of the orthogonalized $\mathrm{U}_{i j}$ tensor.

Table III. Selected Bond Lengths (pm) and Angles (deg) for 3

\begin{tabular}{llll}
\hline $\mathrm{Zn}(1)-\mathrm{N}(5)$ & $192.1(3)$ & $\mathrm{Zn}(1)-\mathrm{N}(2)$ & $198.4(2)$ \\
$\mathrm{P}(1)-\mathrm{N}(1)$ & $157.78(13)$ & $\mathrm{P}(1)-\mathrm{N}(2)$ & $160.7(2)$ \\
$\mathrm{P}(1)-\mathrm{N}(3)$ & $165.4(2)$ & $\mathrm{P}(1)-\mathrm{N}(4)$ & $165.7(2)$ \\
$\mathrm{Si}(1)-\mathrm{N}(2)$ & $173.8(2)$ & $\mathrm{Si}(2)-\mathrm{N}(5)$ & $170.75(15)$ \\
$\mathrm{N}(2)-\mathrm{Zn}(1)-\mathrm{N}(2 \mathrm{a})$ & $111.91(10)$ & $\mathrm{N}(5)-\mathrm{Zn}(1)-\mathrm{N}(2)$ & $124.04(5)$ \\
$\mathrm{N}(1)-\mathrm{P}(1)-\mathrm{N}(2)$ & $115.62(11)$ & $\mathrm{N}(1)-\mathrm{P}(1)-\mathrm{N}(3)$ & $108.25(8)$ \\
$\mathrm{N}(2)-\mathrm{P}(1)-\mathrm{N}(3)$ & $108.47(10)$ & $\mathrm{N}(1)-\mathrm{P}(1)-\mathrm{N}(4)$ & $107.16(11)$ \\
$\mathrm{N}(2)-\mathrm{P}(1)-\mathrm{N}(4)$ & $110.34(10)$ & $\mathrm{N}(3)-\mathrm{P}(1)-\mathrm{N}(4)$ & $106.63(10)$ \\
$\mathrm{P}(1)-\mathrm{N}(1)-\mathrm{P}(1 \mathrm{a})$ & $133.9(2)$ & $\mathrm{P}(1)-\mathrm{N}(2)-\mathrm{Si}(1)$ & $126.32(11)$ \\
$\mathrm{P}(1)-\mathrm{N}(2)-\mathrm{Zn}(1)$ & $113.10(9)$ & $\mathrm{Si}(1)-\mathrm{N}(2)-\mathrm{Zn}(1)$ & $120.51(10)$ \\
$\mathrm{Si}(2)-\mathrm{N}(5)-\mathrm{Si}(2 \mathrm{a})$ & $126.4(2)$ & $\mathrm{Si}(2)-\mathrm{N}(5)-\mathrm{Zn}(1)$ & $116.82(8)$
\end{tabular}

1) with a crystallographic 2 -fold axis through $\mathrm{N}(1), \mathrm{Zn}(1)$, and $N(5)$. A side view perpendicular to this axis (Figure 2) shows that the six-membered cyclozincadiphosphatriazene ring system is slightly twisted. The coordination at the zinc atom is trigonal planar, with a shorter $\mathrm{Zn}-\mathrm{N}$ distance to $\mathrm{N}(5)$ [192.1(3) pm] and two equal distances to the phosphazene nitrogen atoms [N(2), $\mathrm{N}(2 \mathrm{a}): 198.4(2) \mathrm{pm}]$. For comparison the $\mathrm{Zn}-\mathrm{N}$ distance in $\mathrm{O}\left\{\mathrm{O}\left[\mathrm{Me}_{2} \mathrm{SiN}(t-\mathrm{Bu})\right]_{2} \mathrm{Zn}\right\}_{2}$ is $184.3 \mathrm{pm}$ (mean)..$^{13}$

\section{Experimental Section}

All experiments were carried out strictly under a moisture- and oxygen-

(13) Elias, A. J.; Schmidt, H.-G.; Noltemeyer, M.; Roesky, H. W. Eur. J. Solid State Inorg. Chem. 1992, 29, 23-42.

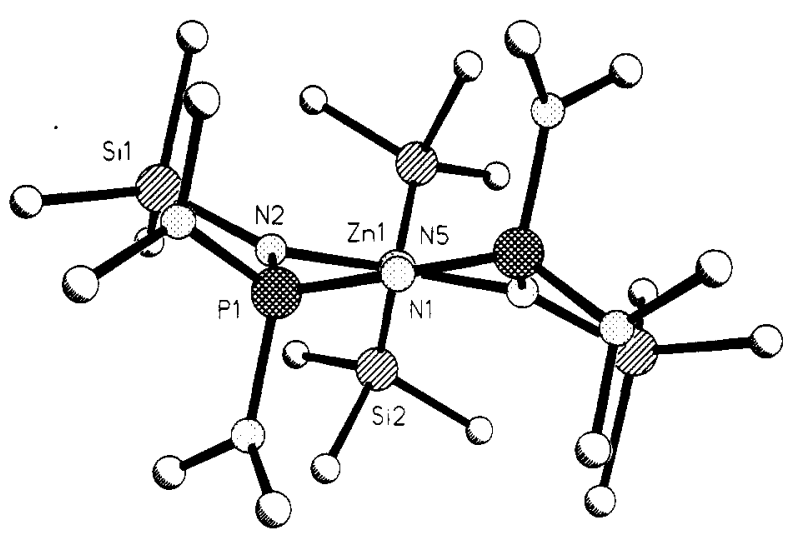

Figure 2. Side view showing the slightly twisted phosphazene ring system in 3.

free nitrogen atmosphere or in vacuo by using Schlenk methods. All solvents were dried and distilled prior to use and stored under dry nitrogen. $\mathrm{ZnCl}_{2}, \mathrm{ZnMe}_{2}$, and $\mathrm{ZnEt}_{2}$ were obtained from Strem Chemicals and Schering AG. $\mathrm{Zn}\left[\mathrm{N}\left(\mathrm{SiMe}_{3}\right)_{2}\right]_{2}$ was prepared by the method described in the literature. ${ }^{14}$

${ }^{1} \mathrm{H},{ }^{29} \mathrm{Si}$, and ${ }^{31} \mathrm{P}$ NMR spectra were recorded by means of a Bruker AM 250 instrument using TMS $\left({ }^{1} \mathrm{H},{ }^{29} \mathrm{Si}\right)$ and $85 \% \mathrm{H}_{3} \mathrm{PO}_{4}\left({ }^{31} \mathrm{P}\right)$ as external standards. Infrared spectra were recorded on a Bio-Rad FTS 7 spectrophotometer. Mass spectrometric analyses were performed with a Finnigan MAT 8230 instrument.

Preparations. [N\{P(NMe $\left.\left.\left.)_{2}\right)_{2} \mathrm{NSiMe}_{3}\right\}_{2} \mathrm{ZnN}\left(\mathrm{SiMe}_{3}\right)_{2}\right]$ (3). A solution of $1(2.0 \mathrm{~g}, 4.7 \mathrm{mmol})$ in $n$-hexane $(20 \mathrm{~mL})$ was added dropwise to an $n$-hexane solution of $\mathrm{Zn}\left[\mathrm{N}\left(\mathrm{SiMe}_{3}\right)_{2}\right]_{2}(1.8 \mathrm{~g}, 4.7 \mathrm{mmol})$, and the contents were heated just below reflux and stirred overnight. The evaporation of all volatiles under reduced pressure resulted in a spectroscopically pure white solid in quantitative yield. $\mathrm{Mp}: 115-120^{\circ} \mathrm{C}$. MS (EI, $\left.m / z\right): 489$ $\left(\mathrm{M}-\mathrm{N}\left(\mathrm{SiMe}_{3}\right)_{2}, 62 \%\right)$. ' $\mathrm{H}$ NMR $\left(\mathrm{CDCl}_{3}\right): \delta 0.10$ (s, 18H, $\left.\mathrm{SiMe}_{3}\right)$, 0.20 (s, $\left.18 \mathrm{H}, \mathrm{NSiMe}_{3}\right), 2.50 \mathrm{ppm}\left(\mathrm{d}, 24 \mathrm{H}, \mathrm{NMe}_{2}, J=10.5 \mathrm{~Hz}\right.$ ). ${ }^{31} \mathrm{P}$ NMR $\left(\mathrm{CDCl}_{3}\right): \delta 20.8 \mathrm{ppm}(\mathrm{s})$. ${ }^{29} \mathrm{Si} \mathrm{NMR}\left(\mathrm{CDCl}_{3}+\right.$ toluene): $\delta-4.8$, $2.3 \mathrm{ppm}$ (s). IR (Nujol): $1287 \mathrm{~b}, 1244 \mathrm{~s}, 1196 \mathrm{~s}, 1145 \mathrm{~m}, 1104 \mathrm{~s}, 1064$ m, 981 vs, 839 vs, $773 \mathrm{~m}, 724 \mathrm{~s}, 675 \mathrm{~m}, 627 \mathrm{~s}, 536 \mathrm{vs}, 506 \mathrm{~s} \mathrm{~cm}^{-1}$.

[N\{P(NMe $\left.\left.\left.)_{2} \mathrm{NSiMe}_{3}\right)\right\}_{2} \mathrm{ZnMe}\right]$ (4). A $2.0-\mathrm{g}$ (4.7- $\left.\mathrm{mmol}\right)$ sample of 1 was dissolved in $n$-hexane $(20 \mathrm{~mL})$. This solution was cooled by liquid air $\left(-193^{\circ} \mathrm{C}\right)$, and $\mathrm{ZnMe}_{2}(0.45 \mathrm{~g}, 4.7 \mathrm{mmol})$ was added by condensation through a vacuum line. Finally the flask was allowed to warm to room temperature, and the mixture was stirred for about $18 \mathrm{~h}$. All volatiles were evaporated under reduced pressure, giving a white solid product in quantitative yield. $\mathrm{Mp}: 103-105^{\circ} \mathrm{C}$. MS (EI, $\left.m / z\right): 490(\mathrm{M}-\mathrm{Me}$, 100\%). ${ }^{1} \mathrm{H} \mathrm{NMR}\left(\mathrm{CDCl}_{3}\right): \delta 0.1\left(\mathrm{~s}, 18 \mathrm{H}, \mathrm{SiMe}_{3}\right), 0.3(\mathrm{~s}, 3 \mathrm{H}, \mathrm{Me})$, $2.6 \mathrm{ppm}\left(\mathrm{d}, 24 \mathrm{H}, \mathrm{NMe}_{2}, J=10.5 \mathrm{~Hz}\right),{ }^{29} \mathrm{Si} \mathrm{NMR}\left(\mathrm{CDCl}_{3}+\right.$ toluene): $\delta-4.5 \mathrm{ppm}(\mathrm{s}) .{ }^{31} \mathrm{P} \mathrm{NMR}\left(\mathrm{CDCl}_{3}\right): \delta 22.3 \mathrm{ppm}$ (s). IR (Nujol): 1287 $\mathrm{m}, 1245 \mathrm{~s}, 1170 \mathrm{~s}, 1135 \mathrm{~m}, 1101 \mathrm{~m}, 981 \mathrm{vs}, 852 \mathrm{~s}, 835 \mathrm{~s}, 780 \mathrm{~m}, 726 \mathrm{~s}$, $679 \mathrm{~m}, 637 \mathrm{~m}, 536 \mathrm{~s}, 505 \mathrm{~m} \mathrm{~cm}^{-1}$. Anal. Calcd for $\mathrm{C}_{15} \mathrm{H}_{45} \mathrm{~N}_{7} \mathrm{P}_{2} \mathrm{Si}_{2} \mathrm{Zn}$ $\left(M_{\mathrm{r}}\right.$ 507.01): C, 35.5; H, 8.9; N, 19.3. Found: C, 34.8; H, 8.6; N, 18.5.

[N\{P(NMe $\left.\left.)_{2} \mathrm{NSiMe}_{3}\right\}_{2} \mathrm{ZnEt}\right]$ (5). A $2.0-\mathrm{g}(4.7-\mathrm{mmol})$ sample of 1 and $0.58 \mathrm{~g}$ of $\mathrm{ZnEt}_{2}(4.7 \mathrm{mmol})$ were used for the reaction. The experimental details were the same as for compound 4. 5 was obtained as a white semisolid. MS (EI, $m / z): 517(\mathrm{M}-2 \mathrm{H}, 4 \%), 427(\mathrm{M}-\mathrm{ZnEt}$, 20\%), $75\left(-\mathrm{PNMe}_{2}, 100 \%\right) .{ }^{1} \mathrm{H} \mathrm{NMR}\left(\mathrm{CDCl}_{3}\right): \delta 0.05\left(\mathrm{~s}, 18 \mathrm{H}, \mathrm{SiMe}_{3}\right)$, $0.20\left(\mathrm{~m}, 3 \mathrm{H}, \mathrm{CH}_{3}\right), 1.20\left(\mathrm{t}, 2 \mathrm{H}, \mathrm{CH}_{2}\right), 2.60 \mathrm{ppm}\left(\mathrm{d}, 24 \mathrm{H}, \mathrm{NMe}_{2}, J=\right.$ $10.5 \mathrm{~Hz})$. ${ }^{31} \mathrm{P}$ NMR $\left(\mathrm{CDCl}_{3}\right) ; \delta 22.0 \mathrm{ppm}(\mathrm{s})$. IR (Nujol): $1289 \mathrm{~m}$, $1245 \mathrm{vs}, 1180 \mathrm{~s}, 1135 \mathrm{~m}, 1097 \mathrm{~m}, 981 \mathrm{vs}, 851 \mathrm{~m}, 835 \mathrm{~s}, 781 \mathrm{~m}, 727 \mathrm{~s}$, $679 \mathrm{~m}, 628 \mathrm{~m}, 537 \mathrm{~s}, 505 \mathrm{~s} \mathrm{~cm}^{-1}$.

X-ray Measurements of 3. The intensities for the structure were collected on a Stoe-Siemens AED instrument with graphite-monochromated Mo K $\alpha$ radiation $(\lambda=71.073 \mathrm{pm}$ ). Data were collected from an oil-coated rapidly-cooled crystal at $-120^{\circ} \mathrm{C}$ with a profile-fitted method. ${ }^{15}$ The structure was solved by Direct Methods ${ }^{16}$ and refined by full-matrix least-squares procedures against $F^{2},{ }^{17}$ All non-hydrogen atoms were refined anisotropically, and the hydrogen positions were set geometrically.

(14) Haaland, A.; Hedberg, K.; Power, P. P. Inorg. Chem. 1984, 23, 1972

(15) Clegg, W. Acta Crystallogr. 1981, A37, 22.

(16) Sheldrick, G. M. Acta Crystallogr. 1990, A46, 467.

(17) Sheldrick, G. M.SHEL XL-92 program for crystal-structure refinement. University of Göttingen, 1992. 
A weighting scheme of the form $w^{-1}=\sigma\left(F_{0}{ }^{2}\right)+\left(g_{1} P\right)^{2}+g_{2} P$ with $P=$ $\left(F_{0}^{2}+2 F_{\mathrm{c}}^{2}\right) / 3$ was introduced.

Acknowledgment. We thank the Deutsche Forschungsgemeinschaft and the Fonds der Chemischen Industrie for financial support. S. K. P. is grateful to the Alexander von Humboldt
Foundation for a postdoctoral fellowship.

Supplementary Material Available: Tables of crystallographic parameters, hydrogen atomic coordinates and isotropic thermal parameters, anisotropic thermal parameters, and bond distances and angles for 3 (4 pages). Ordering information is given on any current masthead page. 